\title{
APULEIUS'S FABULA MILESIA \\ IN THE CONTEXT OF THE FRAME ANALYSIS
}

\author{
Olga Lefterova \\ $\mathrm{PhD}$, Associate Professor, Taras Shevchenko National University of Kyiv, Ukraine \\ e-mail: olefterova@gmail.com,orcid.org/0000-0003-0659-1334
}

\section{Andrii Galaidin}

Ph.D. student, Polonia University in Czestochowa, Interdisciplinary Faculty, Poland e-mail: a.galaidin@ap.edu.pl,orcid.org/0000-0002-5236-1495

\section{Summary}

The article analyzes Apuleius's novel "Metamorphoseon" (Latin Metamorphoseon) or "The Golden Donkey" (Latin Asinus aureus) in the context of the frame approach. Apuleius's novel is of great interest for research, as there, in the depths of a single linguistic picture of the author's worldview there are two hypostases of language - profane and mythopoetic, serving the basis for the representation of the sacred holistic concept of worldview. This study grounds the need for forming research strategies based on the construction of a genre frame and taking into account the genre characteristics of the ancient text. The purpose of this study is to analyze the text of the ancient Latin novel as a certain hierarchical structure. The latin text of the novel "The Golden Donkey" served as the research material. Based on the example of the text extract analysis, an attempt is made to reproduce the process of forming a genre frame. The process of interpreting the genre of the Roman novel can be represented as a process of forming a static genre frame and its transformation into a dynamic genre frame, where the static frame is presented at the level of rethinking the mystery traditions of ancient culture, and a dynamic frame is shown in the context of recursive art technique (mise en abyme), typical for the creative manner of Apuleius. Analysis of "The Golden Donkey" in the context of frame scenarios suggests that Apuleius, consciously sought to avoid genre certainty, which later served as a basis for the formation of new directions in European literature.

Keywords: Apuleius, "The Golden Donkey", ancient Latin novel, genre frame, Fabula Milesia, transformation.

DOI https://doi.org/10.23856/3911

\section{Introduction}

Nowadays people are still trying to understand the philosophical concept of metempsychosis, get to know the sacred aspects of human existence, so the ancient text "The Golden Donkey", which recreates the idea of mystical transformations in a light casual manner, is attractive to both an average reader and a researcher. Remaining incredibly modern today, this amazing story conveys throughout thousands of years the content of ancient initiations and ancient mysteries, which, oddly enough, are becoming more relevant every year.

Apuleius's novel is of great interest for research, as there, in the depths of a single linguistic picture of the author's worldview there are two hypostases of language - profane and mythopoetic, serving the basis for the representation of the sacred holistic concept of worldview.

The topicality of this study is determined by the originality of the novel "The Golden Donkey", which on the one hand, can be interpreted as an adventure novel, and on the other hand, as 
a novel-initiation, involving the interpretation of an array of philosophical issues. Fabula Milesia,

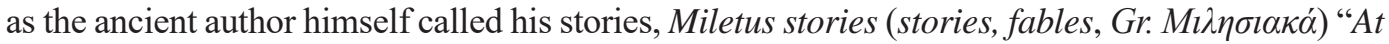
ego tibi sermone isto Milesio varias fabulas conseram..." (Apuleius,2020) are small folk tales of cheerful, mostly erotic or spicy content, which originated in Miletus. G. Jensson defines a Miletus story as a subtype of the novel, written as a first-person narrative (Griffiths, 1975). The narrator describes his journey from memory, successfully weaving meetings with other characters and their stories into the outline of the text. The main difficulty in understanding Apuleius's text is the increased metaphorical nature of his work, as the same character can denote different ideas, two characters can merge into one, and one or another phenomenon of the natural world or artifact can stand for another higher entity or be predicted as such.

Therefore, the analysis of the deep structures embedded in the texts of Apuleius, necessitates the expansion of the traditional study of the ancient novel genre. The transition to a new level of text analysis from the standpoint of heuristics and nonlinear approach to textual studies creates new opportunities for the study of the author's text in the framework of cognitive linguistics through frames and scripts.

Despite the fact that today there is a sufficient number of works in which an attempt is made to give a theoretical justification for the frame, this concept has not yet found a clear interpretation in linguistics, so a holistic, systematic understanding of general directions of frame analysis is missing, which affects its quality (Sologub, 2009: 98). The purpose of this study is to analyze Apuleius's Miletus stories as a certain hierarchical structure in the context of genre frame theory. The latin text of the novel "The Golden Donkey" served as the research material.

\section{Theoretical foundations of genre frame research}

The theoretical foundations of the frame study in linguistics is presented in the works by S. A. Zhabotynska, V. V. Honcharenko and E. A. Shynhareva, A. H. Baranova, N. S. Husareva, O. P. Sologuh, T. N. Korzh et al. According to A. H. Baranov's definition, frames are the representation form of knowledge not only about the external objective world in its statics and dynamics, but also about language and ways of its use in acts of communication (Baranov, 1985). That is, the frame, on the one hand, contains knowledge about human activity, on the other hand, it is a tool for reproducing human speech activity. Two elements that are inextricably linked can be distinguish in the frame, namely the stereotypical situation, i.e. the image as a holistic nonverbal reflection of reality in the mind and the data that interpret it and act as a means of verbal expression of this image-stereotype (Gusarova, 2014: 15). Analysis of frame organization at the text level allows to fill the lacunes and establish the identity between different linguistic-cultural and linguistic-stylistic aspects of utterances in the studied text. Since the frame is a data structure for representing a stereotypical situation, so such a stereotypical situation will be the genre of the text, which is a relatively stable thematic, compositional and stylistic type of expression (Korzh, 2016: 56). In this paper the genre frame is considered as a mental representation of a genre form and type of visualization for stages of text interpretation and analysis (Korzh, 2016: 53-54). The formation of the genre frame takes place at the stage of linguistic and cultural analysis, which includes extralinguistic and linguistic information about the original. The selection of the genre frame allows not only to stereotype the perception of artistic texts samples, but also to use it as a support in the text study and the reconstruction of the mental-authorial worldview. In the process of lingual and cultural analysis of artwork, the knowledge that exists in the form of static frames is transformed into a dynamic frame under the influence of the original text. 
Genre frame determines the nature of the object's speech activity, his language behavior within a certain communicative situation (Sologub, 2009: 101).

\section{Genre affiliation of "Fabula Milesia"}

Apuleius's novel "The Golden Donkey" has its own specific features and own peculiarities, inherent only to it. The most important thing in the novel is metamorphosis. The transformation can be of different nature. The main character, called Lucius, being interested in magic, wants to turn into a bird, however, an assistant in this difficult procedures makes a mistake, consequently, Lucius turns into a donkey. In the likeness of a donkey, Lucius suffers from humiliation and torment. At the end of the novel, it appears that Lucius punishment is due to the fact that the young man fell into the bondage of carnal pleasures.

Apuleius's "The Golden Donkey" is a text filled with stories that, although not directly related to the protagonist, are organically linked to the main idea of the work. However, according to other researchers, Apuleius's novel does not have a single idea, the author cares primarily about the impression created by each story individually, and not the whole book as a whole (Finkelpearl, 1999: 234-244). Therefore, the genre of the work remains uncertain.

The ambiguity of the Latin word fabula, ea f, (Oxford Classiacal Dictionary, 2016) used by Apuleius himself further complicates the understanding of the text genre. In the novel prologue he points out the connection of the work with Miletus stories, which are small narratives of cheerful, mostly erotic or spicy content, written by Aristide of Miletus. This connection is mentioned again in Book IV, which tells about Milesiae conditor, i.e. the "founder" of the genre of Miletus narrative. Another interesting detail is the Miletus origin of one of "The Golden Donkey" characters, called Telephron (Graverini, 2007: 124), which can be considered a genre marker of the work (Apuleius, 2020: 2.21).

The uncertainty of the nature of the "Miletus genre" among the researchers of "The Golden Donkey" raises many questions (Burnell, 1997: 53), since "high" and "low" (or "limited" and "wide, general") culture in Apuleius merge and flow one into another, as in the story of Cupid and Psyche, which the author presented for the general public as a bold, "low" humor, comedic Miletus story (Robiano, 2000: 511-12). However, despite the frivolous nature of the work, Miletus' stories, written by Apuleius, served as a background for the development of various types of transformations and allegories, the nature of which can be explored through the interpretation of key symbols, which, on the one hand, indicate a set of facts to be restored within a certain context for its adequate perception, on the other hand, preserve a genetic connection with the object of extralingual activity, which is based on the transfer of meaning for different degree of imagery.

\section{Transformations and their multilevel implementation in the text of "The Golden Donkey"}

Semiotic interpretation of reality goes through the entire artistic essence of the work, moving from local fragments to the general idea. Thus, the protagonist Lucius, transformed into a donkey due to Photida's mistake, in applying transformation magic, goes through various trials, trying to regain his human form. This is reminiscent of the Psyche's story, which also includes dangerous curiosity (Shumate, 1999: 99), punishment for it, performance of difficult tasks and redemption through the service to the deity.

Without resorting to the analysis of Cupid and Psyche's story (Apuleius,2020: 4), we note that its leading idea, which is inextricably linked with the main motif of the novel, needs separate consideration, since the story of the winged god Cupid and ordinary, though beautiful, 
but mortal earthly woman Psyche can be interpreted as a story about obtaining sacred knowledge, and the image of Psyche is revealed in several guises: she is the one who discovers divine secrets, and the soul which psychopump Mercury escorts to the underground chambers, and the initiator experiencing symbolic death. The image of Psyche is fundamentally ambiguous and the analysis of image transformations will allow researchers to look differently at the mythopoetic context of the Miletus stories of Apuleius.

On the other hand, research in the context of frame analysis allows interpretation of Psyche and Cupid's adventures as a venture and suggests that the author blames Psyche's actions on the girl herself (and that she also blames herself for what happened) (Perry, 1926) and the realities of everyday life (a woman persecutes a husband (Psyche persecutes Cupid), and the girl's family does her more harm than good (sisters conspire to become her husband's mistresses, and mother-in-law envies and mocks).

Supporting the then popular tradition of scandalous stories, Apuleius portrays female figures in an ironic manner. Even divine omniscience does not always help the Olympians, for example, an ordinary seagull fools Aphrodite, whispering to her the gossips about Psyche (Apuleius ,2020:5.28).

In general, the behavior of neither the goddess nor the earthly woman is highly moral, for example, Aphrodite loses control over her behavior, screams, loses her temper towards Psyche (Apuleius, 2020: 5, 122), Psyche does not restrain herself, especially when it comes to revenge (similar the motif will later appear in Giambattista Basile's fairy tale "Cenerentola"). Thus, realizing what her sisters wanted, the heroine persuades them to jump off the sacrificial rock, lying that Cupid wants to have each of them for a new wife (Apuleius, 2020: 5.26).

The example of Cupid and Psyche' story shows that the realms of gods, people, animals and plants can not exist separately from each other, constantly intertwined and intersecting with each other.

The same statement is true for the main characters of the work. The first-person narrative "Metamorphosis" allows to achieve considerable flexibility in its characterization. Apuleius created interesting and lively characters who acted as the driving force of the plot. However, the basis of the plot line development was not the main characters' heroic deeds, but mistakes in decision-making and haste. The main character Lucius gets into troubles due to his own carelessness and extreme curiosity. Though, Lucius is obviously ashamed to admit such a trait of his, which he does not call "curiositas". We can assume that if the protagonist was honest with himself, the result of his metamorphosis would be different (Joly, 1961). Lucius goes through various trials, trying to regain his human form. His story is similar to the story of Psyche (Shumate, 1999: 99). Similar to Psyche's story, "curiositas" (curiosity) is his main motivation for all the main character's actions. In fact, the main plot line of the book, i.e. the accidental transformation of a man into a donkey, reinforces this idea. Throughout Apuleius' text, the boundaries between the worlds of humans and animals, humans and plants, animate and inanimate are gradually blurred. Using not only straightforward metamorphoses, but also small, seemingly invisible, linguistic means (especially in the lexical scope of the novel), he skilfully creates ambiguity, uncertainty between representatives of all categories. For example, when writing about trees, Apuleius uses the word "brachiorum" instead of "ramorum", which either uses one of the meanings of "brachiorum", or is a euphemism for "ramorum", i.e. compares the branches of trees with human hands. (Apuleius 2020: 11.14).

However, even when Lucius finally manages to regain his human likeness and ability to speak and return to his place in human society, the boundaries between the realms of man and nature still remain blurred (Apuleius 2020: 11.14). 
Therefore, it is no coincidence that at the moment of transformation from Lucius-donkey into Lucius-man, a wreath of roses appears (corona rosea; corona rosis amoenis intexta). According to Kasyan's idea, "corona rosea" - the wreath of roses in Apuleius is an essential element of the compositional metaphor, the so-called compositional code of the novel, which unites the inserted stories (Kasyan, 2012).

\section{Conclusions and suggestions}

Apuleius's novel can be represented as a genre frame of a certain hierarchical structure, consisting of vertices and connections between them. The upper level of the frame displays basic information about the state of the object, which is always identical to the probable situation, and is described by a series of short stories, the central of which is a short story about Cupid and Psyche, a prologue, containing numerous hints about the nature of the future story, and an all-encompassing motif, which is represented by one or another phenomenon of the natural world, such as the roses that the hero dreams of eating, starting from the third chapter (Apuleius, 2020: 3. 25) and until the last one (Apuleius, 2020: 11. 6), when he, finally, sees "wreath of roses" (roseam coronam) during the sacred procession in the hands of the priest. The lower level is represented by slots that contain specific meanings, can be varied and supplemented with new information through the interpretation of key symbols (phytonyms and zoonyms). Analysis of the lower level slots will allow us to trace the connection between "Metamorphosis ..." and well-known fairy tales, such as "Town Musicians of Bremen" by the Brothers Grimm, "Beauty and the Beast" by Jeanne-Marie Leprince de Beaumont.

Given the above, the interpretation process of the Roman novel genre can be represented as a process of forming a static genre frame and its transformation into a dynamic genre frame at the stage of researching author's text-source, where the static frame is presented at the level of rethinking the foundations of the mysterious traditions of ancient culture, and the dynamic frame is realized as varietas in the context of recursive artistic technique (mise en abyme), characteristic of the creative style of Apuleius. Analysis of the work in the context of frame scenarios suggests that Apuleius, focused on artistic search, consciously sought to avoid genre certainty, which later served as a basis for the emergence of new directions in European literature. However, this hypothesis requires further research.

\section{References}

Apuleius (2020). Metamorphoses. [Electronic resource]. Retrieved from https://www.thelatinlibrary.com/apuleius.html. [in Latin].

Baranov ,A. G. (1985). Kognitivnyiy komponent vyiskazyivaniya i teksta [Cognitive component of utterance and text]. Aktualizatsiya lingvisticheskih edinits raznyih urovney. Krasnodar: Sb.nauchn.tr., 21-28 [in Russian].

Burnell, P. (1987). The Death of Turnus and Roman Morality, Greece \& Rome 2nd series 34.2, 186-200. [in English].

Finkelpearl, E. D. (1990). Psyche, Aeneas and an Ass: Apuleius Metamorphoses. 6.10-6.21. Transactions of the American Philological Association . Vol. 120, 333-347. [in English].

Graverini, L. (2007). The Ass's Ears and the Novel's Voice. Orality and the Involvement of the Reader In Apuleius' Metamorphoses. University of Siena. [in English].

Griffiths, J. G. (1975) Apuleius of Madauros. The Isis - Book (Metamorphoses, Book XI). Leiden. [in English]. 
Gusarova, N.S.( 2014) Freym - yedinitsa vyskazyvaniya i perevoda [Frame is a unit of expression and translation]. Vestnik Rossiyskogo universiteta druzhby narodov. Seriya: Teoriya yazyka. Semiotika. Semantika. Moscow, № 4, 15-23. [in Russian].

Joly, R (1961) Curiositas. In: L'antiquité classique, t. 30, 33-44 [Electronic resource].Retrieved from https://www.persee.fr/doc/antiq_0770-2817_1961_num_30_1_3402 [in English].

Kasyan, M. S. (2012). Rosea corona i kompozitsiya «Metamorfoz» Apuleya [Rosea corona and composition "Metamorphosis" by Apuleius]. [Electronic resource]. Retrieved from https:// cyberleninka.ru/article/n/rosea-corona-i-kompozitsiya-metamorfoz-apuleya . [in Russian].

Korzh, T. N. (2016). Obucheniye perevodu russkoyazychnykh khudozhestvennykh tekstov s oporoy na zhanrovyy freym [Teaching the translation of Russian-language literary texts based on the genre frame]. Yazyik i kultura. Moscow, 51-64. [in Russian].

Lefkowitz, M. R.(1990) Women in Greek Myth, 2nd ed. Baltimore: John Hopkins University Press. [Electronic resource].Retrieved from https://jhupbooks.press.jhu.edu/title/women-greekmyth [in English].

Oxford Classical Dictionary. (2016) Online dictionary. [Electronic resource]. Retrieved. https://oxfordre.com/classics/view/10.1093/acrefore/9780199381135.001.0001/acrefore-9780199381135-e-2626 [in English].

Perry B. E. (1926). An Interpretation of Apuleius' Metamorphoses // Transactions and Proceedings of the American Philological Association. Vol. 57, 238-260. [Electronic resource]. Retrieved from https://www.jstor.org/stable/282773?read-now=1\&refreqid=excelsior\%3A83 fb4d38b6559df270340d1004097edf\&seq=1\# [in English].

Robiano, P. (2000). La citation poétique dans le roman érotique grec. REA 102, 509-529. [in French].

Shumate N. (1999). Apuleius Metamorphoses. The inserted tales // Latin Fiction The Latin Novel in Context ed. by Heinz Hofmann. N.Y., Komdon, 96-106. [in English].

Sologub, O. P. (2009). Osobennosti realizatsii zhanrovogo freyma v kommunikativnoy situatsii "obrashcheniye $v$ ofitsial'nuyu instantsiyu»[ Features of the implementation of the genre frame in the communicative situation "appeal to the official instance]. Voprosy kognitivnoy lingvistiki. Moscow. № 2,98-106. [in Russian]. 